\title{
Effect of Api-Tulle Dressing versus the Conventional Dressing Technique on the Healing of Moderate Burns
}

\author{
Hanaa Abbass Ahmed, Demonstrator \\ Medical Surgical Nursing, Faculty of Nursing, Alexandria University \\ Sanaa Mohamed Alaa Eldeen, Professor \\ Vascular Surgery, Faculty of Medicine, Alexandria University \\ Fayza Mohamed Tawfeek, Lecturer \\ Medical Surgical Nursing, Faculty of Nursing, Alexandria University
}

\begin{abstract}
Burns exert a catastrophic influence on people in terms of human life, suffering, disability, and financial loss. Regarding burn wound care, the appropriate selection of a topical therapeutic agent can improve the healing of wounds and lead to decreased patient morbidity. Apitherapy is method of utilizing products from the honeybee including raw honey for health benefits. Api-Tulle dressing technique is a type of Apitherapy. It is one of the promising alternative techniques for wound care. Objective: To compare the effect of ApiTulle dressing versus the conventional dressing technique on the healing of moderate burns. Settings: The study was conducted at the burn unit of Raas El-Teen El-Aam Hospital in Alexandria. Subjects: The total sample of 40 adult patients admitted to burn unit suffering from moderate burn were included, Patients were divided randomly into two groups of equal size (20 patients, each). The first 20 patients were managed by conventional dressing technique. The second 20 patients were managed using Api-Tulle dressing. Tools: Two tools were used for data collection. The first tool (Burn patient assessment sheet) was obtained from the subjects and their hospital chart at first date of data collection and tool two (Burn wound evaluation sheet) was applied at admission then weekly until complete wound healing occurred. Results: The main results of this study revealed that, regarding wound healing morphology, healthy granulation tissues and proliferation of epithelial cells occurs in ApiTulle group patients more rapidly than conventional group and there were significant difference between the two dressing techniques at the first, second, third and fourth weeks. In Relation to signs of burn wound infection, the majority of Api-Tulle group patients (85\%) did not have edema and reddish discoloration. Where, more than half of the conventional group (55\%) had edema and reddish discoloration of wound after the first week. Hyperthermia and elevation of white blood cells level (WBCs) occurred for conventional group patients with a significant difference between the both groups. Conclusion: The use of Api-Tulle wound dressings have a positive effects on wound healing and combating infection in comparison with conventional dressings. Recommendations: Using Api-Tulle dressing technique for moderate burn wound management at burn unit and further studies are needed for the effectiveness of Api-Tulle dressing on severe burn injury.
\end{abstract}

\section{Introduction}

Burns exert a catastrophic influence on people in terms of human life, suffering, disability, and financial $\operatorname{loss}{ }^{(1)}$. Progress in the management of burn patients continues at a rapid pace and has led to dramatic reductions in morbidity and mortality. Despite this, burn injuries are the second leading cause of accidental death in the USA following automobile crashes $^{(2,3)}$, Runyan (2004) reported that burn is the 
third leading cause of fatal home injury ${ }^{(4,5)}$ and Centers for Disease Control and Prevention (CDC) (2005) pointed that burn is the fifth most common cause of unintentional injury deaths in the United States ${ }^{(6-8)}$.

In Egypt, in 2007, the statistical records of the Burns Unit at the Main University Hospital in Alexandria revealed an admission rate of 373 patients and death rate of 88 patients $^{(9)}$. In addition, the admission rate to burn units of Raas ElTeen El-Aam hospital was 242 patients with 47 deaths in the same year ${ }^{(10)}$.

Although advances in burn care have reduced mortality rates, infection remains one of the most challenging concerns for the burn team. Burn wound infection can be managed by rapid burn debridement, following infection control precautions and the use of effective topical and systemic antimicrobial therapy to enhance rapid wound healing ${ }^{(11,12)}$.

Burn wound care exists in the acute/intermediate phase of burn care ${ }^{(12)}$. The major goals of burn wound care are: to foster the development of granulation tissue, promote re-epithelialization, and prepare the wound for grafting if necessary. Other goals are to prevent infection through using appropriate antimicrobial agents and wound debridement. In addition, the reduction of scarring and contractures is a priority. Finally, is to provide comfort to patient ${ }^{(13)}$.

Silver sulfadiazine is currently the most topical antibacterial agent extensively used for burn care. Recent findings, however, indicate that the compound delays the wound-healing process and that silver may have serious cytotoxic activity on various host cells $^{(12,14,15)}$.

The current prevalence of antibioticresistant microbial species has led to a reevaluation of the therapeutic use of ancient remedies. One of the promising solutions for burn wound infection is the use of Apitherapy. It is an established form of alternative therapy and is practiced by thousands of medical professionals and practitioners $^{(16,17)}$. Apitherapy is a therapeutic use of bee products including bee venom, bee pollen, raw honey and propolis $^{(18)}$. The history of Apitherapy can be traced back to the ancient Egypt, Greece, and India. Where bee products can be used as healthy foods and can be used in the treatment of wounds ${ }^{(19)}$.

Honey is a supersaturated sugar solution with approximately $17.1 \%$ water. Fructose is the predominant sugar at $38.5 \%$, followed by glucose at $31 \%$. Disaccharides, trisaccharides and oligosaccharides which are present in much smaller quantities. Besides carbohydrates, honey contains small amounts of protein, (including enzymes), vitamins, organic acids, and minerals $^{(20-25)}$.

Not all types of honey have the same level of antibacterial activity though; honey processed for use in wound care is passed through fine filters which remove most of the pollen. It is a cold-pressed honey, not heated above high temperature then sterilized by gamma irradiation to destroy spores of Colestridium Botulinum into the wound ${ }^{(26,27)}$.

Api-Tulle dressing is a special dressing soaked with Api-Care honey which is not a commercial honey but it is sterilized to be used as a wound dressing. It is licensed under the Egyptian Ministry of Health. Each $100 \mathrm{gm}$ of the ointment contains $85 \mathrm{gm}$ of active pure honey (non commercial) with special specifications.

Clinically, topical honey treatment has been shown by (White and Molan 2005): that honey possesses antimicrobial properties, osmotic effect, promote debridement, stimulate anti-inflammatory activity that rapidly reduces pain, edema and exudates, and minimizes hypertrophic scarring, and promote moist wound healing ${ }^{(28,29)}$. 


\section{Aim of the Study}

The aim of this study was to compare the effect of Api-Tulle dressing versus the conventional dressing technique on the healing of moderate burns.

\section{Materials and Method}

Materials

Design: A quasi-experimental research design was used to conduct the study.

Settings: The study was carried out at the burn unit of Raas El-Teen El-Aam hospital affiliated to Ministry of Health and Population in Alexandria.

Subjects: A convenience sample of (40) adult moderately burned patients were included in the study. They were divided equally into Api-Tulle and conventional groups, 20 patients in each group.

Subject inclusion criteria were:

- Age: adult 18-50 years.

- Recently moderately burned patients with second degree burns of $15 \%$ $25 \%$ total body surface area, and third degree burns of less than $10 \%$ total body surface area not involving special care areas (eyes, ears, face, hands, feet, and perineum).

- Normal body mass index (19-24 $\mathrm{kg} / \mathrm{m}^{2}$ ).

- Not high-risk patients (suffering from chronic disease).

Tools: Two tools were used for data collection:

\section{Tool I: Burn Patient Assessment}

This tool included the following:

\section{A. Biosociodemographic data:}

It comprised the patient age, sex, marital status, level of education, residence, occupation, date of burn, date of admission, and date of discharge.

\section{B. Burn parameters:}

Including cause of burns, extent (total body surface area burned), and degree of burns (either partial thickness or mixed partial and full thickness burn).

\section{Type of dressing:}

Two methods of dressing were used either Api-Tulle dressing or conventional dressing.

\section{Tool II: Burn Wound Evaluation}

This included:

\section{A. Vital signs follow up:}

Including Temperature $\left(\mathrm{C}^{\mathrm{o}}\right)$, Pulse rate $(\mathrm{b} / \mathrm{m})$, respiratory rate $(\mathrm{c} / \mathrm{m})$, and blood pressure $(\mathrm{mmHg})$.

\section{B. Nutritional follow up:}

This part included information about patient's body mass index follow up ( $\mathrm{pt}$ weight in $\mathrm{kg} / \mathrm{pt}$ height in meter $^{2}$ ) in $\left(\mathrm{kg} / \mathrm{m}^{2}\right)$.

\section{Laboratory studies follow up:}

Complete blood count (red blood cells (RBCs), hemoglobin (Hb), platelets, white blood cells (WBCs), total protein and Serum albumin.

D. Morphological changes of the wounds:

The wound was assessed in relation to the stage of wound healing weekly:

- Normal findings of wound healing:

i. Presence of healthy granulation tissues.

ii. Proliferation of epithelial cells

- Abnormal findings of wound healing:

i. Necrotic tissues.

ii. Progression of partial-thickness to full-thickness injury.

iii. Change in wound color (red, brown, Violaceous, Green or black discoloration). 
iv. Subeschar hemorrhage.

v. Rapid eschar separation.

\section{E. Photographic Pictures:}

Photographs were taken to assess progress of wound healing process.

\section{Method}

- Permission to carry out the study was obtained from the director of Raas El-Teen El-Aam hospital after explanation of the purpose of the study.

- Tools were developed by the researcher based on review of literature, content validity was tested by 9 experts in the filed of medical surgical nursing. The required corrections and modifications were carried out accordingly.

- Pilot study done on five patients that were selected conveniently to check and ensure clarity and applicability of the tools

- The researcher introduced herself to every subject patient including in the study, explained the purpose of the study. Patient's written consent to participate in the study was then obtained. Every patient was informed that confidentiality will be assured.

- Api-Tulle dressing was used for study group by the researcher. Dressing was done at patient's room two times daily (8 Am and 8 Pm); blister and dead tissues not removed; the wounds was cleansed with normal saline $(0.9 \%)$ solution; Api-Tulle dressing was applied directly on wounds ;light dressing and gauze bandage with minimum pressure applied on wound. (*the size of Api-Tulle dressing is $10 \mathrm{~cm}$ $\times 10 \mathrm{~cm}$ ). Control group received a conventional wound care according to burn unit routine.
- Both groups received dressing under infection control precautions either surgical asepsis (use of sterile gloves, cover sterile equipments, not to cross sterile surface, sterile only touch sterile, sterile equipments kept above waist level) or medical asepsis ((i.e., gowns, gloves, and masks) the unit has its own laundry, intensive care unit ( 2 beds), the rooms' capacity (1,2 or maximum 3 beds), and no visitor enter the unit.

- Tool one data were obtained from the subject and his hospital chart at first meeting with the patient.

$>$ Extent of burn was estimated using the Lund and Browder chart ${ }^{(30)}$.

- Tool two (Burn wound evaluation sheet) was applied at admission then weekly until complete wound healing occurred.

- Patient assessment was done at 8am after removal of all clothes (except hospital gown) and old dressing and before application of new dressing.

- The period of data collection lasted for 12 months during the period between Octobers 2007and September 2008.

\section{Ethical considerations:}

Confidentiality and privacy of patient's data were asserted. Participation in the study was voluntary, with the patient right to withdraw at any time.

\section{Statistical Analysis}

Data of the obtained result were tabulated and presented in frequency distribution tables. Findings were presented in number and percentages. Data analysis was carried out by computer using the SPSS.

The statistical analyses used were: the mean, standard deviation, chi-square $\left(\chi^{2}\right)$, and fisher exact test (FET). The level of 
significant for the study was $p<0.05$. Graphs were done for data visualization using Microsoft Excel.

\section{Results}

The main results of this study have revealed that, there were no statistical difference between Api-Tulle group and conventional group patients regarding biosociodemographic characteristics and there are no correlation between any of biosociodemographic characteristics and wound healing. (65\%) of both groups patients had partial thickness burn injury $(15-25 \%)$, and the majority of them $(65 \%$ $\& 80 \%$ ) were burned as result of dry thermal injury.

Table (1) shows the effect of the ApiTulle technique versus conventional one for moderately burned patients on vital signs changes. Concerning body temperature, on admission approximately three quarters of both Api-Tulle group and conventional patients were having normal body temperature $(75.0 \%, 85.0 \%)$ with no significant difference $(p=0.230)$. After the first and second weeks, about the entire Api-Tulle group patients had normal body temperature $(100 \%$ \& $95 \%)$. Where, more than half of the conventional group patients were having normal body temperature $(55 \%$ $\& 60 \%$ ), with a significant difference $(p=0.001 \& 0.009)$. Body temperature of both Api-Tulle and conventional group patients were approximately normal after the fourth, fifth, and six weeks of hospitalization.

As for pulse rate, about two thirds of both Api-Tulle and conventional group patients had normal pulse rate on admission $(65 \%) \&(75 \%)$. Pulse rate of Api-Tulle group patients' returned to normal after first week. While, for conventional group patients return to their normal heart rate gradually through second, and third weeks $(80 \%, 90 \%)$ to fourth, fifth, and six weeks $(100 \%, 100 \%, 100 \%)$ respectively.
Regarding blood pressure level and respiratory rate, almost all of both ApiTulle and conventional group patients were having normal blood pressure levels and respiratory rate through out the study period.

Table (2) shows the effect of the ApiTulle technique versus conventional one for moderately burned patients on their laboratory investigations for the 1st, 2nd, and third week. On admission the level of WBCs was normal in both groups $(100 \%$, $100 \%)$. While, after the first, second, and third weeks WBCs level were normal in all the Api-Tulle group patients levels compared to the conventional group ones as $(80 \%, 75 \%, 85 \%)$ of them had normal WBCs levels. However there was a significant difference just after the second week $(0.024)$

As for RBCs, Platelets, Hemoglobin, protein and serum albumin levels they were normal in both groups and no changes were noticed all over the period of data collection.

Figure (1) shows the effect of the ApiTulle technique versus conventional one for moderately burned patients on their healthy granulation tissues. The mean percentage of healthy granulation tissues at first and second weeks for Api-Tulle group patients $(22.1 \% \& 48.1 \%)$ respectively was approximately twofold the conventional group ones $(10.05 \% \quad \& \quad 24.15 \%)$ respectively. The table also illustrates that at the third week the mean percentage of healthy granulation tissues for Api-Tulle group patients was $(72.55 \%)$. While, for the conventional group the mean was $(45.37 \%)$.

There was significant differences between the two dressing techniques at the first, second, third and fourth weeks $(\mathrm{t}=5.630,6.005,4.486,2.465)$ respectively $(\mathrm{P}=0.000)$.

Figure (2) shows the effect of the ApiTulle technique versus conventional one for moderately burned patients on their proliferation of epithelial cells. The results 
revealed that the mean percent of proliferation of epithelial cells of Api-Tulle group patients at first week $(12.31 \%)$ was approximately 4 times greater than conventional group $(3.3 \%)$. At the second and third weeks the mean percent of proliferation of epithelial cells of Api-Tulle group patients $(26.2 \% \quad \& \quad 44.95 \%)$ respectively was around two times superior to the conventional group ones $(9.15 \%$ \& $22.85 \%$ ) respectively. At the fourth week the majority of the Api-Tulle group patients were discharged. Whereas, the conventional group patients continued with wound healing progress through the fourth, fifth, and sixth weeks.

There was significant difference between the two dressing techniques at the first, second, third and fourth weeks $(\mathrm{t}=4.956,5.041,4.677,2.313)$ respectively $(\mathrm{P}=0.000)$.

Table (3) shows the effect of the ApiTulle technique versus conventional one for moderately burned patients on their abnormal morphologic changes of wound healing. The majority of Api-Tulle group patients $(85 \%)$ had not shown any reddish discoloration. Where, approximately half of the conventional group (55\%) had edema and reddish discoloration of wound after the first week.

Regarding black discoloration, quarter of both Api-Tulle and conventional group patients were experiencing black discoloration after the first week but this resolved for both groups after that.

Nearly none of studied patients either Api-Tulle or conventional experience abnormal brown wound discoloration through out the study period.

None of the studied patients experienced violaceous discoloration of wound, subeschar hemorrhage, early eschar separation, and progression of partialthickness to full-thickness injury.

Figure (3) shows the effect of the ApiTulle technique versus conventional one for moderately burned patients on hospitalization period. The results revealed that most of Api-Tulle group patients' $(85 \%)$ hospitalization period ranged from 20 and less than 30 day. Where, around half of conventional group patients $(45 \%)$ were hospitalized for period between 30to 40 days. with a significant difference between the two groups $\left(\chi^{2}=13.260, \mathrm{P}<0.05\right)$.

\section{Discussion}

The use of honey in the treatment of wounds, burns and skin ulcers originated with ancient civilizations, but was superseded by modern dressings and antibiotic therapy. To date, the evidence to support the efficacy of honey in wound healing is largely anecdotal, but there are many claims that as a dressing on wounds, it reduces inflammation, debrides necrotic tissues, reduces edema and promotes angiogenesis, granulation and epithelialization $^{(31)}$.

Going with this context, the present study was conducted in order to evaluate the effect of Api-tulle dressing versus the conventional dressing technique on the healing of moderate burns.

The results of the present study demonstrate that, there were no statistical differences between the Api-tulle group and conventional group regarding biosociodemogrraphic data, but revealed that there was a significant difference between the Api-tulle group and conventional group regarding healing morphology (granulation, and epithelialzation), hospitalization period, and local signs of infection.

This study results showed that, on admission approximately one quarter of both Api-Tulle group and conventional patients had high body temperature. This may be due to normal inflammatory response after burn injury. After the first week body temperatures of Api-Tulle group patients were approximately normal for the rest of study period. On the other hand, more than one third of conventional group patients' had high body temperatures after 
the first and second weeks; and approximately all of them returned to normal temperatures after that. This is in contradiction with a study done at Tanta University by Ragab (2002) to evaluate the effectiveness of two dressing techniques on healing of recent moderately burn wounds who reported that most of the traditional group were having hyperthermia for about three weeks after burn injury. Also added that this may be attributed to nursing staff practices that not following strict aseptic technique strictly during wound dressing ${ }^{(32)}$.

As for pulse rate, about two thirds of both Api-Tulle and conventional group patients were having normal pulse rate on admission. This is predictable with the initial reaction to burn injury. Pulse rate of Api-Tulle group patients' returned to normal after that. While, for conventional group patients' returned to their normal heart rate gradually through second, and third weeks till the six week. Consequently, this makes a significant difference between the Api-Tulle group and the conventional group. These results are supported by Ragab (2002) at Tanta University who reported significant differences in pulse rate between traditional technique and wet exposed technique $^{(32)}$.

Almost all of both Api-Tulle and conventional group patients were having normal respiratory rate and blood pressure level through out the study period; Comparing to that of Ragab study (2002) who found significant differences between the studied groups in relation to respiratory rate and blood pressure measurement ${ }^{(32)}$.

As for laboratory investigations, on admission the level of WBCs was normal in both groups. While, after the first, second, and third weeks WBCs level were normal only in all the Api-Tulle group patients as compared to the conventional group ones whose only around three quarters of them had normal WBCs levels over the first three weeks. This may explain the delay in healing for the conventional group wounds and prolonged hospitalization period. This results is in line with Osman (2003), who reported that laboratory investigations have demonstrated superior results with honey compound $^{(33)}$.

As regard RBCs, Platelets, Hemoglobin, and protein levels they were normal in both groups and not changed allover the period of data collection. In contrast, Abdel-hamid (2009) in her study pointed that the percentage of normal values for hemoglobin, hemotacrit, total proteins, serum albumin and albumin/globin ratio were decreased. This difference in results may be due to her study of wound healing as the only concerns were with burn hands regardless of any burns on other sites of the $\operatorname{body}^{(34)}$.

There was a statistical significant difference between the Api-Tulle group and conventional group patients' regarding hospitalization period and as the Api-Tulle group patients were discharged earlier as compared to the conventional ones; this is supported by study done by Ragab $(2002)^{(32)}$. Who explained the result and supported the use of natural antimicrobial agents for managing burn wounds. In addition evaluating the effects of topical application of honey on burn wound in relation to hospital stay; the honey-treated group was $22.0 \pm 1.2$ days versus $32.3 \pm 2.0$ in the other group ${ }^{(35)}$.

Analysis of wound morphology records in the present study showed a high statistical difference in both granulation proportions between the studied groups as granulation occurred in the Api-Tulle group wounds more rapidly than the conventional ones. This is in line with Subrahmanyam et al (2001) who claimed a statistical difference between patients treated with honey, (wounds healed by mean period of 15.4 days) and patients treated with silver sulphadiazine (mean period of healing was 17.2 days $)^{(35)}$. Similar results were mentioned by Abd-Elaziz (2005) who reported effect of honey dressing on diabetic foot ulcers and found that honey treated group had faster healing than other 
groups treated with betadine $10 \%$ dressing or dermagrane dressing ${ }^{(36)}$. Another supporting study was reported by Abd ElHaleem (2005) to manage gynecological post operative wounds with honey ${ }^{(37)}$. In addition Subrahmanyam (1998) claimed that honey treated wounds were clean, tidy, and healthily granulating all the time, while silver-sulphadiazine-treated wound were almost covered by a purulent exudates with an untidy granulating surface ${ }^{(38)}$.

In the present study epithelialization occurred earlier in the Api-Tulle group than conventional ones. This result was in line with the results of Subrahmanyam (1998) In India who reported that, $84 \%$ of the wounds treated with honey showed satisfactory epithelialization by the 7th day, and in $100 \%$ of the patients by the 21 st day. In wounds treated with silver sulfadiazine, epithelialization occurred by the 7 th day in $72 \%$ of the patients and in $84 \%$ of patients by 21 days $^{(38)}$.

Allergic reactions to honey are rare and have been attributed in some cases to a reaction to presence of pollen in the honey ${ }^{(35)}$. The study revealed that Irritation, allergy and other side effects were not observed in any of Api-Tulle treated patients. This may be attributed to honey used in Api-Tulle dressing processed for use in burn wound care by being passed through fine filters which remove most of the pollen and has been treated by gamma-irradiation to kill clostridial spores without loss of any of the honey antibacterial activity.

Abdel-hamid (2009) mentioned that all burn wounds are contaminated with bacteria. Whether a wound becomes infected or not is determined by the host's immune competence and the size of the bacterial inoculums. With normal host defenses and adequate debridement, a wound may bear a level of 100,000 $\left(10^{5}\right)$ microorganisms per gram of tissue and still heal successfully; beyond this number, a wound may become infected ${ }^{(34)}$.
In the present clinical study wound infection manifestations statistically differentiate between the Api-Tulle group and conventional group where the Api-Tulle group experience less wound infection signs than the conventional group. This result is supported by study done by Subrahmanyam (1998) who reported that $80 \%$ of wounds treated with the honey dressing healed with minimal inflammation. While, $52 \%$ of the silver sulfadiazine treated wounds showed reparative activity with inflammatory changes as wound discoloration (red, brown, black, violet or green), wound edema, subesccher hemorrhage, or conversion of partial thickness to full thickness injury. Thus in honey dressed wounds, early subsidence of acute inflammatory changes, better control of infection and quicker wound healing was observed while in the silver sulfadiazine treated wounds sustained inflammatory reaction was noted even on epithelialization $^{(38)}$.

The laboratory findings for Api-care honey (which is used in development of Api-Tulle dressing) in Alexandria University in the Faculty of Pharmacology revealed that Api-care honey is superior to silver sulfadiazine in controlling most common types of micro-organisms. This is in line with Subrahmanyam (2001) who proved that honey is more effective in the sterilization of burn wounds than silver sulphadiazine ${ }^{(35)}$.

\section{Conclusion}

The main results of this study have revealed that, there is no statistical difference between Api-Tulle group and conventional group patients regarding biosociodemographic characteristics. There is no correlation between any of biosociodemographic characteristics and wound healing.

Regarding wound healing morphology, healthy granulation tissues and proliferation of epithelial cells occurs in Api-Tulle group patients more rapidly than 
conventional group ones and there was significant difference between the two dressing techniques at the first, second, third and fourth weeks.

Hyperthermia occurs for conventional group patients with a significant difference for the Api-Tulle group patients during assessment on the first and second weeks, and elevation of white blood cells level (WBCs) on the second and third weeks for $(20 \% \& 25 \%)$ of conventional group patients versus none of the Api-Tulle group patients.

Also, the present finding conclude that, the mean hospitalization period for Api-Tulle patients group was 23 days while, it increased to 33 days for the conventional group patients.

\section{Recommendations}

Based on finding of this study, the following recommendations can be suggested:

\section{Regarding the burn unit:}

- Presence of specialized nurse at burn unit for wound care management.

- In-service training program for burn unit staff about: a) Different techniques of burn wound care as Api- Tulle dressing technique.

b) Patients nutritional needs and importance to follow nutritional regimen

c) Universal standards and infection control precautions (medical and surgical asepsis) at the burn unit for burn injury management.

d) Increase staff awareness of outpatients burn clinic about efficacy of using Api- Tulle dressing technique for burn wounds.

\section{Further researches:}

- Evaluate the effect of Api- Tulle dressing on severe burn wounds.

- Evaluate the effect of Api- Tulle dressing on other wounds as post-operative wounds and chronic ulcers.

- Determine the effects of other natural antimicrobial agents as olive oil, aloevera on the healing of burn wounds.

- Developing standards of care for burn wound management are needed to be in Alexandria University Hospital. 
Table (1): Effect of the Api-Tulle technique versus conventional one for moderately burned patients on vital signs changes

\begin{tabular}{|c|c|c|c|c|c|c|c|c|c|}
\hline \multirow{2}{*}{ 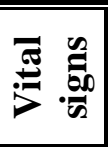 } & \multirow{2}{*}{ Time } & \multirow{2}{*}{\multicolumn{2}{|c|}{$\begin{array}{c}\text { Pts No. at } \\
\text { beginning of } \\
\text { each week }\end{array}$}} & \multicolumn{2}{|c|}{ Conventional } & \multicolumn{2}{|c|}{ Api-Tulle } & \multirow{2}{*}{$\chi^{2} /$ FET } & \multirow{2}{*}{$\mathbf{P}$} \\
\hline & & & & No. & $\%$ & No. & $\%$ & & \\
\hline \multirow{7}{*}{ 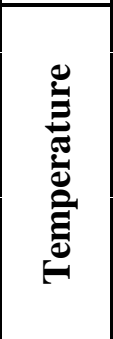 } & admission & $>\mathrm{C}=20$ & $\rightarrow \mathrm{A}=20$ & 17 & 85 & 15 & 75 & 0.625 & 0.23 \\
\hline & $1^{\text {st }}$ week & $\mathrm{C}=20$ & $A=20$ & 11 & 55 & 20 & 100 & 11.610 & $0.001^{\text {* }}$ \\
\hline & $2^{\text {nd }}$ week & $\mathrm{C}=20$ & $A=20$ & 12 & 60 & 19 & 95 & 7.025 & $0.009^{\text {* }}$ \\
\hline & $3^{\text {rd }}$ week & $\mathrm{C}=20$ & $A=20$ & 16 & 80 & 20 & 100 & 4.444 & 0.035 \\
\hline & $4^{\text {th }}$ week & $C=15$ & $A=4$ & 14 & 93.3 & 4 & 100 & 0.281 & 0.596 \\
\hline & 5th week & $\mathrm{C}=8$ & $A=0$ & 8 & 100 & $\begin{array}{l}--- \\
-\end{array}$ & ---- & ---- & ---- \\
\hline & 6th week & $\mathrm{C}=4$ & $A=0$ & 4 & 100 & ---- & ---- & ---- & ---- \\
\hline \multirow{7}{*}{ 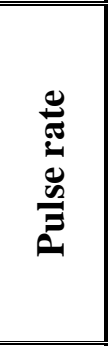 } & admission & $\mathrm{C}=20$ & $A=20$ & 15 & 75 & 13 & 65 & 0.476 & 0.215 \\
\hline & $1^{\text {st }}$ week & $\mathrm{C}=20$ & $A=20$ & 13 & 65 & 20 & 100 & 8.485 & $0.004^{\text {** }}$ \\
\hline & $2^{\text {nd }}$ week & $\mathrm{C}=20$ & $A=20$ & 16 & 80 & 20 & 100 & 4.444 & 0.053 \\
\hline & $3^{\text {rd }}$ week & $C=20$ & $A=20$ & 18 & 90 & 20 & 100 & 2.105 & 0.147 \\
\hline & $4^{\text {th }}$ week & $C=15$ & $A=4$ & 15 & 100 & 4 & 100 & ---- & ---- \\
\hline & $5^{\text {th }}$ week & $\mathrm{C}=8$ & $A=0$ & 8 & 100 & --- & ---- & --- & ---- \\
\hline & $6^{\text {th }}$ week & $\mathrm{C}=4$ & $A=0$ & 4 & 100 & ---- & ---- & ---- & ---- \\
\hline \multirow{7}{*}{ 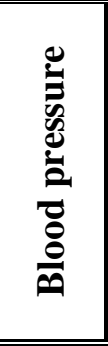 } & admission & $\mathrm{C}=20$ & $A=20$ & 19 & 95 & 20 & 100 & 1.026 & 0.311 \\
\hline & $1^{\mathrm{st}}$ week & $C=20$ & $A=20$ & 20 & 100 & 20 & 100 & ---- & ---- \\
\hline & $2^{\text {nd }}$ week & $C=20$ & $A=20$ & 20 & 100 & 20 & 100 & ---- & ---- \\
\hline & 3rd week & $\mathrm{C}=20$ & $A=20$ & 20 & 100 & 20 & 100 & --- & ---- \\
\hline & $4^{\text {th }}$ week & $C=15$ & $A=4$ & 15 & 100 & 4 & 100 & ---- & ---- \\
\hline & $5^{\text {th }}$ week & $\mathrm{C}=8$ & $A=0$ & 8 & 100 & --- & ---- & ---- & ---- \\
\hline & $6^{\text {th }}$ week & $\mathrm{C}=4$ & $\mathrm{~A}=0$ & 4 & 100 & ---- & ---- & ---- & ---- \\
\hline \multirow{7}{*}{ 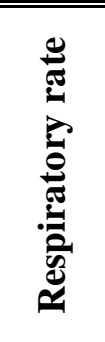 } & בadmission & $\mathrm{C}=20$ & $A=20$ & 19 & 95 & 20 & 100 & 1.026 & 0.311 \\
\hline & $1^{\text {st }}$ week & $\mathrm{C}=20$ & $A=20$ & 17 & 85 & 20 & 100 & 3.243 & 0.072 \\
\hline & $2^{\text {nd }}$ week & $\mathrm{C}=20$ & $A=20$ & 20 & 100 & 20 & 100 & ---- & ---- \\
\hline & $3^{\text {rd }}$ week & $\mathrm{C}=20$ & $A=20$ & 20 & 100 & 20 & 100 & ---- & ---- \\
\hline & $4^{\text {th }}$ week & $C=15$ & $A=4$ & 15 & 100 & 4 & 100 & ---- & ---- \\
\hline & $5^{\text {th }}$ week & $\mathrm{C}=8$ & $A=0$ & 8 & 100 & ---- & ---- & --- & ---- \\
\hline & $6^{\text {th }}$ week & $\mathrm{C}=4$ & $A=0$ & 4 & 100 & ---- & ---- & ---- & ---- \\
\hline
\end{tabular}


Table (2): Effect of the Api-Tulle technique versus conventional one for moderately burned patients on their laboratory investigations

\begin{tabular}{|c|c|c|c|c|c|c|}
\hline \multirow{3}{*}{$\begin{array}{l}\text { Laboratory } \\
\text { investigations }\end{array}$} & \multirow{3}{*}{ Time } & \multicolumn{4}{|c|}{ Type } & \multirow{3}{*}{$\mathbf{P}$} \\
\hline & & \multicolumn{2}{|c|}{$\begin{array}{c}\text { Conventional } \\
\mathbf{N}=20\end{array}$} & \multicolumn{2}{|c|}{$\begin{array}{c}\text { Api-Tulle } \\
\mathbf{N}=20\end{array}$} & \\
\hline & & No. & $\%$ & No. & $\%$ & \\
\hline \multirow{4}{*}{ WBCs } & on admission & 20 & 100 & 20 & 100 & \multirow{4}{*}{$\begin{array}{c}1 \\
0.053 \\
0.024 \text { * } \\
0.115\end{array}$} \\
\hline & $1^{\text {st }}$ week & 16 & 80 & 20 & 100 & \\
\hline & $2^{\text {nd }}$ week & 15 & 75 & 20 & 100 & \\
\hline & $3^{\text {rd }}$ week & 17 & 85 & 20 & 100 & \\
\hline \multirow{4}{*}{ RBCs } & " on admission & 20 & 100 & 20 & 100 & \multirow{4}{*}{$\begin{array}{c}---- \\
---- \\
---- \\
---- \\
\end{array}$} \\
\hline & $1^{\text {st }}$ week & 20 & 100 & 20 & 100 & \\
\hline & $2^{\text {nd }}$ week & 20 & 100 & 20 & 100 & \\
\hline & $3^{\text {rd }}$ week & 20 & 100 & 20 & 100 & \\
\hline \multirow{4}{*}{ Platelets } & on admission & 20 & 100 & 20 & 100 & \multirow{2}{*}{$\begin{array}{l}---- \\
----\end{array}$} \\
\hline & $1^{\text {st }}$ week & 20 & 100 & 20 & 100 & \\
\hline & $2^{\text {nd }}$ week & 20 & 100 & 20 & 100 & ---- \\
\hline & $3^{\text {rd }}$ week & 20 & 100 & 20 & 100 & ---- \\
\hline \multirow{4}{*}{ Hemoglobin } & on admission & 20 & 100 & 20 & 100 & \multirow{2}{*}{$\begin{array}{l}----- \\
----\end{array}$} \\
\hline & $1^{\text {st }}$ week & 20 & 100 & 20 & 100 & \\
\hline & $2^{\text {nd }}$ week & 20 & 100 & 20 & 100 & ---- \\
\hline & $3^{\text {rd }}$ week & 20 & 100 & 20 & 100 & ---- \\
\hline \multirow{4}{*}{$\begin{array}{l}\text { Blood } \\
\text { protein }\end{array}$} & on admission & 20 & 100 & 20 & 100 & \multirow{4}{*}{$\begin{array}{c}----- \\
---- \\
---- \\
----\end{array}$} \\
\hline & $1^{\text {st }}$ week & 20 & 100 & 20 & 100 & \\
\hline & $2^{\text {nd }}$ week & 20 & 100 & 20 & 100 & \\
\hline & $3^{\text {rd }}$ week & 20 & 100 & 20 & 100 & \\
\hline
\end{tabular}

(䊎) statistically significant $(\mathrm{P} \leq 0.05)$ 


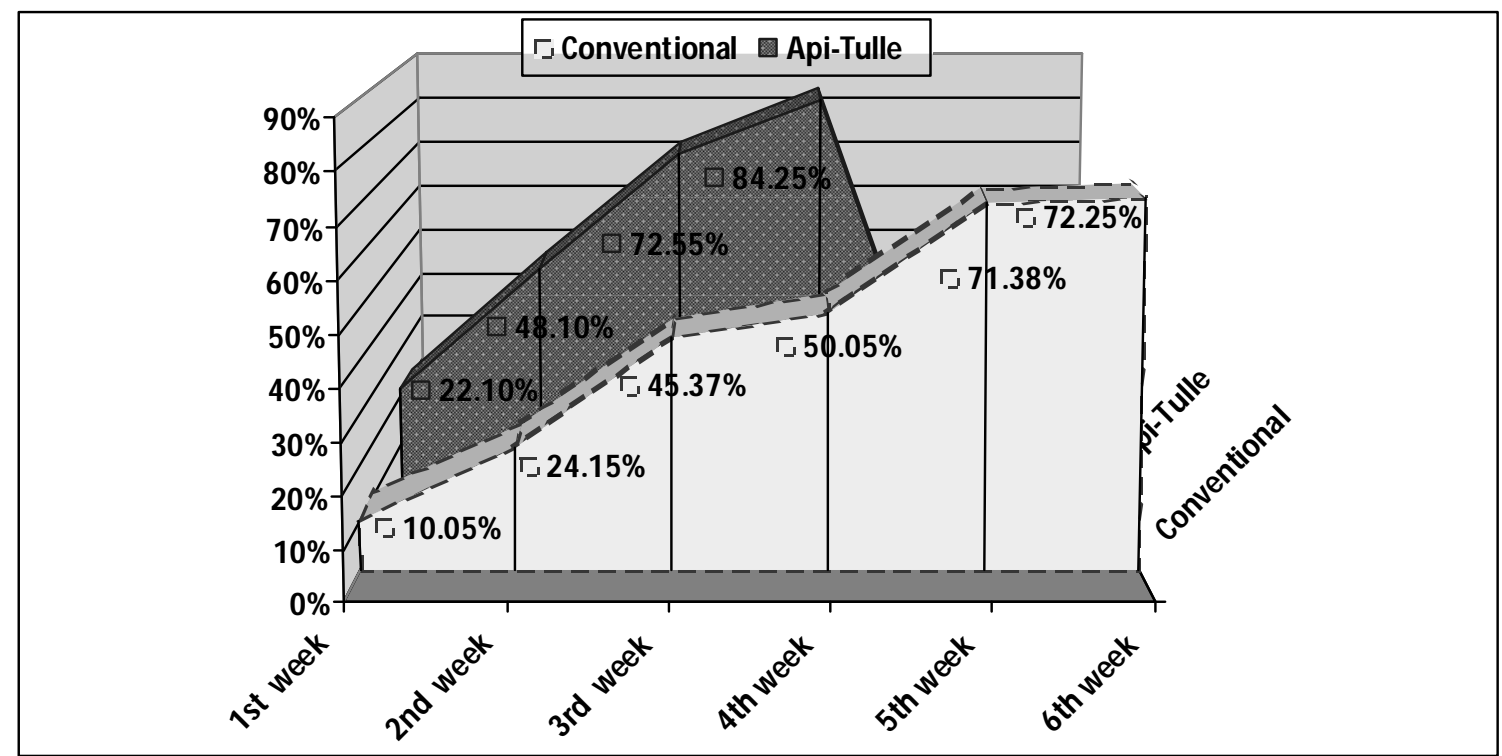

Figure (1): Effect of the Api-Tulle technique versus conventional one for moderately burned patients on their healthy granulation tissues

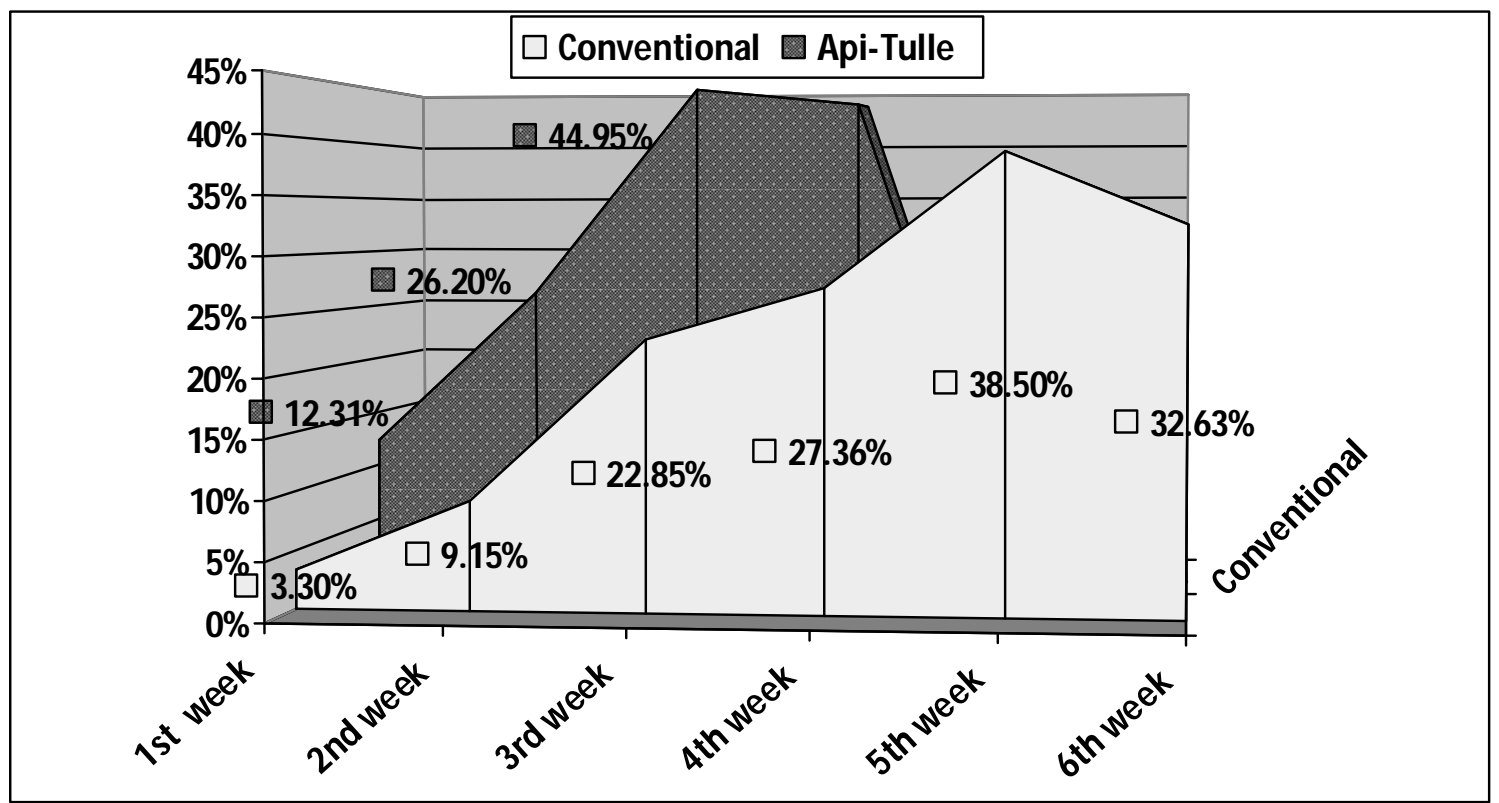

Figure (1): Effect of the Api-Tulle technique versus conventional one for moderately burned patients on their proliferation of epithelial cells 
Table (3): Effect of the Api-Tulle technique versus conventional one for moderately burned patients on their abnormal morphologic changes of wound healing

\begin{tabular}{|c|c|c|c|c|c|c|c|c|}
\hline \multirow{3}{*}{$\begin{array}{c}\text { Abnormal } \\
\text { morphologic } \\
\text { changes }\end{array}$} & \multirow{3}{*}{ Time } & \multirow{3}{*}{\multicolumn{2}{|c|}{$\begin{array}{c}\text { Pts No. at } \\
\text { beginning of } \\
\text { each week }\end{array}$}} & \multicolumn{4}{|c|}{ Type } & \multirow{3}{*}{$\mathbf{P}$} \\
\hline & & & & \multicolumn{2}{|c|}{ Conventional } & \multicolumn{2}{|c|}{ Api-Tulle } & \\
\hline & & & & No. & $\%$ & No. & $\%$ & \\
\hline \multirow{6}{*}{$\begin{array}{l}\text { Edema \& } \\
\text { Red } \\
\text { discoloration }\end{array}$} & $1^{\text {st }}$ week & $\mathrm{C}=20$ & $A=20$ & 11 & 55 & 3 & 15 & $0.008^{*}$ \\
\hline & $2^{\text {nd }}$ week & $\mathrm{C}=20$ & $A=20$ & 8 & 40 & 0 & 0 & $0.002^{*}$ \\
\hline & $3^{\text {rd }}$ week & $\mathrm{C}=20$ & $A=20$ & 1 & 5 & 0 & 0 & 0.5 \\
\hline & $4^{\text {th }}$ week & $C=15$ & $A=4$ & 0 & 0 & 0 & 0 & ---- \\
\hline & $5^{\text {th }}$ week & $\mathrm{C}=8$ & $A=0$ & 0 & 0 & 0 & 0 & 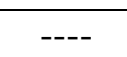 \\
\hline & $6^{\text {th }}$ week & $\mathrm{C}=4$ & $A=0$ & 0 & 0 & 0 & 0 & ---- \\
\hline \multirow{6}{*}{$\begin{array}{l}\text { black } \\
\text { discoloration }\end{array}$} & 1 $^{\text {st }}$ week & $\mathrm{C}=20$ & $\mathrm{~A}=20$ & $\overline{5}$ & 25 & 7 & 35 & 0.215 \\
\hline & $2^{\text {nd }}$ week & $\mathrm{C}=20$ & $A=20$ & 0 & 0 & 0 & 0 & 1 \\
\hline & $3^{\text {rd }}$ week & $\mathrm{C}=20$ & $A=20$ & 0 & 0 & 0 & 0 & 1 \\
\hline & $4^{\text {th }}$ week & $\mathrm{C}=15$ & $A=4$ & 0 & 0 & 0 & 0 & ---- \\
\hline & $5^{\text {th }}$ week & $\mathrm{C}=8$ & $A=0$ & 0 & 0 & 0 & 0 & ---- \\
\hline & $6^{\text {th }}$ week & $\mathrm{C}=4$ & $\mathrm{~A}=0$ & 0 & 0 & 0 & 0 & ---- \\
\hline \multirow{6}{*}{$\begin{array}{l}\text { Brown } \\
\text { discoloration }\end{array}$} & $\mathbf{1}^{\text {st }}$ week & $\mathrm{C}=20$ & $\mathrm{~A}=20$ & 0 & 0 & 1 & 5 & 0.5 \\
\hline & $2^{\text {nd }}$ week & $\mathrm{C}=20$ & $A=20$ & 1 & 5 & 0 & 0 & 0.5 \\
\hline & $3^{\text {rd }}$ week & $\mathrm{C}=20$ & $A=20$ & 0 & 0 & 0 & 0 & 1 \\
\hline & $4^{\text {th }}$ week & $C=15$ & $A=4$ & 0 & 0 & 0 & 0 & ---- \\
\hline & $5^{\text {th }}$ week & $\mathrm{C}=8$ & $\mathrm{~A}=0$ & 0 & 0 & 0 & 0 & ---- \\
\hline & $6^{\text {th }}$ week & $\mathrm{C}=4$ & $\mathrm{~A}=0$ & 0 & 0 & 0 & 0 & ---- \\
\hline \multirow{6}{*}{$\begin{array}{l}\text { Green } \\
\text { discoloration }\end{array}$} & 1 $^{\text {st }}$ week & $\mathrm{C}=20$ & $A=20$ & 5 & 25 & 0 & 0 & 0.024 * \\
\hline & $2^{\text {nd }}$ week & $\mathrm{C}=20$ & $A=20$ & 1 & 5 & 1 & 5 & 0.513 \\
\hline & $3^{\text {rd }}$ week & $\mathrm{C}=20$ & $A=20$ & 0 & 0 & 0 & 0 & 1 \\
\hline & $4^{\text {th }}$ week & $C=15$ & $A=4$ & 0 & 0 & 0 & 0 & ---- \\
\hline & $5^{\text {th }}$ week & $\mathrm{C}=8$ & $\mathrm{~A}=0$ & 0 & 0 & 0 & 0 & ---- \\
\hline & $6^{\text {th }}$ week & $\mathrm{C}=4$ & $A=0$ & 0 & 0 & 0 & 0 & ---- \\
\hline
\end{tabular}

$\rightarrow \mathbf{C} \longrightarrow$ conventional group

$\rightarrow \mathrm{A} \rightarrow$ Api-Tulle group

FET $=$ Fisher's Exact Test

(䊏) statistically significant $(\mathrm{P} \leq 0.05)$ 


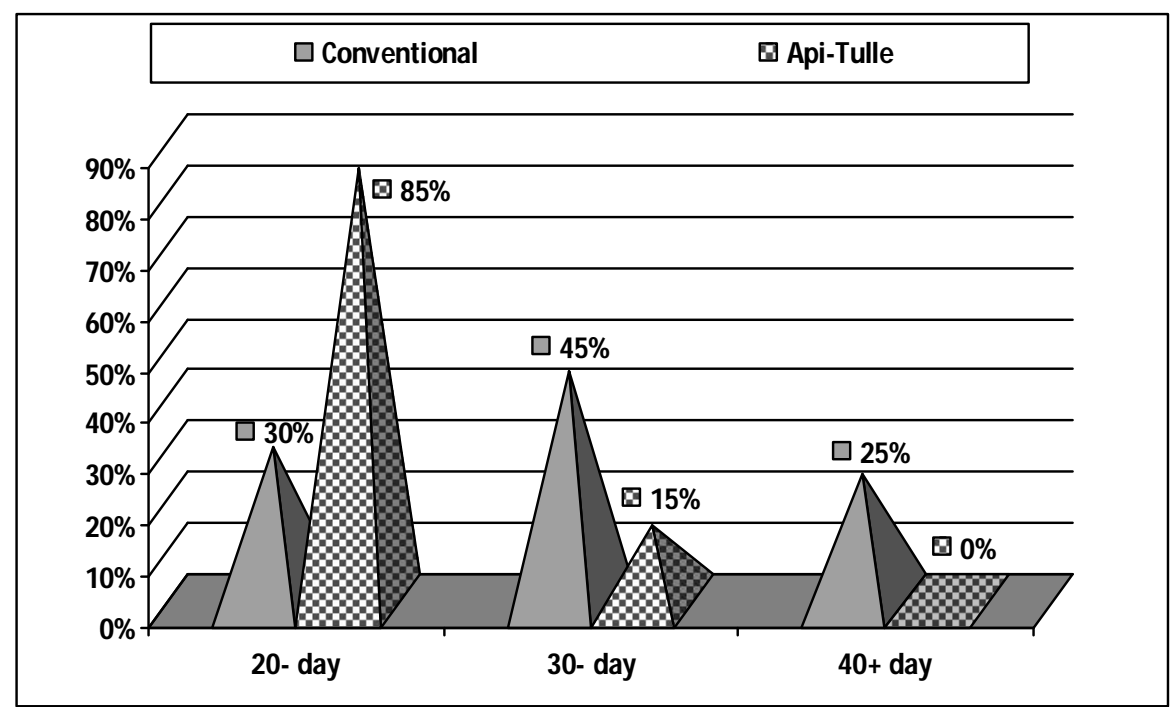

Figure (3): Effect of the Api-Tulle technique versus conventional one for moderately burned patients on hospitalization period 


\section{References}

1. Saffle J, Davis B, Williams P. American Burn Association Registry Participant Group. Recent outcomes in the treatment of burn injury in the United States: a report from the American Burn Association Patient Registry, J Burn Care and Rehabilitation 1995; 16: 21932.

2. Herndon D, Blakeney P. Teamwork for total burn care: achievements, directions, and hopes. In: Herndon D. Total burn care. $2^{\text {nd }}$ ed. Philadelphia, Saunders, 2002.

3. Monahan F, Neighors M, Sands J, Marek J, Green C. Phipps' medical surgical nursing: Health and illness perspective. $8^{\text {th }}$ ed. Mosby, 2007: 1829$65,1911-44$

4. Finkelstein E, Corso P, Miller T. Incidence and Economic Burden of Injuries in the United States. New York: Oxford University Press, 2006.

5. Runyan S, Casteel C. The state of home safety in America: Facts about unintentional injuries in the home, $2^{\text {nd }}$ ed. Washington, D.C.: Home Safety Council, 2004.

6. Centers for Disease Control and Prevention. Injury Statistics Query and Reporting System. National Center for Injury Prevention and Control, 2005. Available at: http://www.cdc.gov/ncipc/wisqars. (Retrieved on: 15/5/2008).

7. Karter M. Fire loss in the United States during 2006. Quincy (MA): National Fire Protection Association, Fire Analysis and Research Division, 2007.

8. Brigham P, Mc-Loughlin E. Burn incidence and medical care use in the United States: estimate, trends, and data sources. J Burn Care and Rehabilitation 2006; 17: 95-107.
9. Statistical records of the burn unit. Alexandria Main University. 2008. (Unpublished data).

10. Statistical records of the burn unit. Raas El-Teen El-Aam hospital affiliated to Ministry of Health and Population in Alexandria. 2008. (Unpublished data).

11. Peck M, Weber J, McManus A, Sheridan R, Heimbach D. Surveillance of burn wound infections: a proposal for definitions. J Burn Care and Rehabilitation 1998; 19:386-9.

12. Rosdahle C, Kowalski M. Textbook of basic nursing. 8th ed. Philadelphia: Lippincott Williams \& Wilkins, 2003.

13. Luckman J, Sorensens K. Medical surgical nursing. 4th ed. Philadelphia: W.B. Saunders Co., 1993; 1988-2010.

14. Cho Lee A, Leem H, Lee J, Park K. Reversal of silver sulfadiazine-impaired wound healing by epidermal growth factor, Biomaterials, 2005; 26 (22): 4670-4676.

15. Fraser J, Cuttle L, Kempf M, Kimble R. Cytotoxicity of topical antimicrobial agents used in burn wounds in Australasia, Journal of Surgery 2004;74 (3): 139-212.

16. Moore O, Smith L, Campbell F, Seers K, McQuay H, Moore A. Systematic review of the use of honey as a wound dressing. BMC Complementary and Alternative Medicine, 2001.

17. Select Committee on Science and Technology. Report No. 7: Resistance to antibiotics and other antimicrobial agents. London: House of Lords, 1998.

18. Tyler C, Varro E. The Honest Herbal: A Sensible Guide to the Use of Herbs and Related Remedies. New York: Pharmaceutical Products Press, 1993. 
19. Allen K, Molan P, Reid G. The variability of the antibacterial activity of honey. Apiacta 1991; 26 (4): 114-121.

20. Angela M, Larry R, Ann M, Carl L, James P, Elwood W. Honey-Health and Therapeutic Qualities. The National Honey Board. 1997. Available at http://www.honeylocator.com. (Retrieved on: 15/5/2008).

21. White J, Subers M, Schepartz A. The identification of inhibine the antibacterial factor in honey, as hydrogen peroxide and its origin in a honey glucose-oxidase system. Biochem. Biopysi. Acta 73: 57-79. In: Mraz, C. Health and the Honeybees. Butlington, USA: Queen City Publishers, 1995; 92.

22. Mcintosh E. American Food Habits in Historical Perspective. Praeger Publishers, Westport, CT, 1995.

23. Ladas, S.D. and Rapitis, S.A. Honey, fructose absorption and the laxative effect. Nutrition 1999; 15(7-8): 591592.

24. Krell, R., Value added products from beekeeping FAO Agricultrural Services Bulletin 124. Rome, Italy: FAO. 1996; 409.

25. Flodhazi, G. Analysis and quantification of sugars in honey of different botanical origin using high performance liquid chromatography. Acta Alimentaria 1994. 23(3): 299-311.

26. Molan P, Allen K. The effect of gamma-irradiation on the antibacterial activity of honey. J Pharm Pharmacol 1996; 48 (11): 1206-9.

27. Postmes T, van den Bogaard A, Hazen M. The sterilization of honey with cobalt 60 gamma radiation: a study of honey spiked with spores of Clostridium botulinum and Bacillus subtilis. Experientia 1995; 51(9-10): 986-9.
28. White R, Molan P. A summary of published clinical research on honey in wound management. In: White $R$, Cooper A, Molan P. Honey: A Modern Wound Management Product. Wounds UK, Aberdeen, 2005; 130-143.

29. White R. The benefits of honey in wound management. Nursing Standard 2005, 20 (10): 57-64.

30. Hettiaratchy S, Papini R. Initial management of a major burn: IIassessment and resuscitation. BMJ 2004; 329: 101-103.

31. Tonks A, Cooper R, Jones K, Blair S, Parton J. Honey stimulates inflammatory cytokine production from monocytes, Cytokine 2003; 21(5,7): 242-247

32. Ragab N. Effectiveness of two dressing techniques on the healing of recent moderately burn wounds. Unpublished Doctoral Thesis, Alexandria, University, Faculty of Nursing, 2002.

33. Osman O, Mansour I, El-Hakim S. Honey compound for wound care: a preliminary report. Annals of Burns and Fire Disasters, September 2003; XVI (3).

34. Abdel-hamid A. Conventional occlusive dressing versus polythene gloving on second-degree burned hands. Unpublished Masters Thesis, Alexandria University, Faculty of Nursing, 2009.

35. Subrahmanyam M, Sahapure A, Nagane $\mathrm{N}$, Bhagwat V, Ganu J. Effects of topical application of honey on burn wound healing. Annals of Burns and Fire Disasters. September 2001; XIV (3).

36. Abd Alaziz A. Comparative study between three wound dressing techniques for patients with diabetic foot ulceration. Unpublished Doctoral 
Thesis, Tanta University, Faculty of Nursing, 2005.

37. Abd El-Haleem M. Effect of topical honey dressing on infected wounds after gynecological and obstetrical abdominal surgery. Unpublished Doctoral Thesis, Tanta University, Faculty of Nursing, 2005.
38. Subrahmanyam M. A prospective randomized clinical and histological study of superficial burn wound healing with honey and silver sulfadiazine. Burns1998; 24(2): 157-161. 